\title{
Saints on Stage: Popular Hagiography in Post-WWII Italy
}

\author{
Daniela Cavallaro
}

Citation: Cavallaro, Daniela. 2021. Saints on Stage: Popular Hagiography in Post-WWII Italy. Religions 12: 216. https://doi.org/ $10.3390 /$ rel12030216

Academic Editor: Salvador Ryan

Received: 6 February 2021

Accepted: 17 March 2021

Published: 21 March 2021

Publisher's Note: MDPI stays neutral with regard to jurisdictional claims in published maps and institutional affiliations.

Copyright: (C) 2021 by the author. Licensee MDPI, Basel, Switzerland This article is an open access article distributed under the terms and conditions of the Creative Commons Attribution (CC BY) license (https:// creativecommons.org/licenses/by/ $4.0 /)$.
School of Cultures, Languages and Linguistics, University of Auckland, Auckland 1010, New Zealand; d.cavallaro@auckland.ac.nz

\begin{abstract}
This article brings to light several examples of the hagiographic plays staged in Italy during the 1950s and early 1960s in parishes, schools, and oratories. The article begins with a brief introduction to the continued tradition of staging the lives of the saints for educational purposes, which focuses on the origins, aims, and main characteristics of theatre for young people of the Salesians, the order founded by Don Bosco in 1859. Next, it offers a brief panorama of the pervasive presence of the lives of the saints in post-WWII Italy. The main discussion of the article concerns the hagiographic plays created for the Salesian educational stages in the years between 1950 and 1965, especially those regarding the lives of young saints Agnes and Domenico Savio. The article concludes that the Salesian plays on the lives of the saints, far from constituting a mere exercise in hagiography, had a definite educational goal which applied to both performers and audiences in the specific times of Italy's reconstruction and the cold war.
\end{abstract}

Keywords: hagiography; Italy; Salesians; Salesian theatre; St Agnes; Domenico Savio

\section{Introduction}

"The Church has always believed that the apostles and Christ's martyrs who had given the supreme witness of faith and charity by the shedding of their blood, are closely joined with us in Christ, and she has always venerated them with special devotion, together with the Blessed Virgin Mary and the holy angels. [ ... ], To these were soon added also those who had more closely imitated Christ's virginity and poverty, and finally others whom the outstanding practice of the Christian virtues and the divine charisms recommended to the pious devotion and imitation of the faithful". These are the words used in chapter VII of Lumen gentium (1964), one of the most significant documents of the Second Vatican Council (1962-1965), to talk about the long Catholic tradition of devotion to the saints. The lives of the saints, the document explains, inspire the faithful to try "to arrive at perfect union with Christ". In fact, Lumen gentium specifies that "we seek from the saints 'example in their way of life, fellowship in their communion, and aid by their intercession'".

Throughout the centuries, popular devotion has honoured the saints, remembered their lives, and asked for their intercession in various ways, from pilgrimages and little altars in the streets, to yearly processions on the saint's feast day, to name just a few. In Italy, where I grew up, specific saints have often been invoked to intercede in matters of importance (the plague, a volcanic eruption) or urgency (a lost item, a sore throat). ${ }^{1}$ A 2006 poll found that more than $70 \%$ of the respondents had an image of a saint at home or in their car. ("E Padre Pio" 2006).

However, while adults, and especially older adults, may ask the saints for intercession, younger Catholics have often been introduced to the saints as role models. Additionally, because young people may not have the patience or inclination to listen to a sermon on the exemplary life of a saint, the saints have frequently been presented on stage. In the years just before the promulgation of Lumen gentium, between the end of WWII and Fascism and the beginning of the economic miracle, most Italian parishes or Catholic schools would have had a theatre on which students and alumni would perform for members of their community - often staging the lives of the saints. 
In this article, I intend to bring to light several examples of the hagiographic plays staged in Italy during the 1950s and early 1960s in parishes, schools, and oratories. I will begin with a brief introduction to the continued tradition of staging the lives of the saints for educational purposes, focusing on the origins, aims, and main characteristics of theatre for young people created by the Salesians, the order founded by Don Bosco in 1859. Next, I will offer a brief panorama of the pervasive presence of the lives of the saints in post-WWII Italy. I will then discuss the hagiographic plays authored for the Salesian educational stages in the years between 1950 and 1965, especially those regarding the lives of young saints Agnes and Domenico Savio. I will conclude by arguing that the Salesian plays on the lives of the saints, far from constituting a mere exercise in hagiography, had a definite educational goal which applied to both performers and audiences in the specific times of the country's reconstruction and the cold war.

\section{Hagiography and Educational Theatre}

For many centuries, Christianity has collected and presented the lives of the saints and martyrs as inspirations and role models for the faithful, or as a tool for the conversion of non-believers. In 15th century Europe, Alison Knowles Frazier explains, the lives of the saints were used in several genres and various locations: they were often the centre of church sermons and outdoor gatherings; they were remembered on their feast-day; they were written in verse and prose to be read by individuals or groups, lay or ordained; and they were represented on stage. "The narration of sanctity", she concludes, occupied several opposing spaces, "oral and literate, popular and elite, official and domestic, peripheral and central, Latin and vernacular, local and universal" (Frazier 2005, p. 9).

The life of a saint in theatrical form, in particular, would also allow a young or illiterate audience to learn about the saint's character and struggles and so was often used in educational settings. Moreover, as Stefano Muneroni points out, the characters of saints and martyrs are many-sided: "they display both divine perfection and human faultiness, and pursue sanctity in the face of their inherent sinfulness" (Muneroni 2017, p. 12). Thus, saints and martyrs, the conflicts they encountered in their lives, and the difficult choices they had to make, are most suitable for dramatic performances as well as role models for the spectators.

Sacre rappresentazioni, plays on the lives of saints and martyrs, were quite popular in convents in Renaissance Italy. In her book Convent Theatre in Early Modern Italy. Spiritual Fun and Learning for Women, Elissa Weaver explains that Italian nuns used theatre in their convents "for their entertainment, as an essential part of the educational program they offered the young schoolgirls in their care, and as a way of attracting the attention of the outside world" (Weaver 2002, p. 1). Convent theatre, in fact, was a moment of shared entertainment for the female wider community that rotated around the convent: relatives, friends, benefactors, mothers of the students (Weaver 2002, pp. 2-3). Stories of martyrs and saints - especially those who could be good role models for the nuns and their pupils - were among the topics chosen for these performances. To Antonia Tanini Pulci (1452-1501), for example, are attributed the Rappresentazione di Santa Domitilla (1483), the Rappresentazione di Santa Guglielma, and the Rappresentazione di San Francesco. ${ }^{2}$ Benedictine nun Cherubina Venturelli is the author of Rappresentazione di Santa Cecilia vergine e martire. ${ }^{3}$

Weaver has suggested that the Society of Jesus, the religious order founded by Ignatius of Loyola in the 16th century, may have been aware of and possibly influenced by the tradition of theatre used in the education of young women in the convents, before the establishment of Jesuit schools (Weaver 2002, p. 4). Certainly, the Jesuits developed a long and successful tradition of having students stage plays as part of their school program.

1 St Rosalia and St Agata, for example, protected the Sicilian cities of Palermo and Catania from the plague and the eruptions from Mt Etna. St Rosalia has more recently also been invoked for protection against Covid-19 (Tondo 2020). For lost objects one prays to St Anthony, while Blaise is the saint who may help a sore throat.

2 See Pulci (1996) and Pulci (2010) for collections of her plays in English.

3 See Bandurski (2009) for a bilingual Italian-English edition of Venturelli's play. 
Students gained exercise in memory and Latin as well as acquiring virtue by emulation. In addition, since Jesuit performances on special occasions (the feast of a patron saint, or a prizegiving ceremony) were open not only to school members but to the entire community, theatre was, in addition, "a form of advertising for Jesuit education, but also [ . . . ] a way of dialogue and alliance with civil and religious authorities" (Gallo 2018). Finally, the public nature of educational theatre helped the schools' prospects of gaining the support of wealthy donors (Sani 2009, p. 44). Again, many of the most famous plays created by Jesuit writers are based on the lives of exemplary saints, from the founders of their order in Apotheosis sive consecractio SS. Ignatii et Francisci Xaverii [The apotheosis or consecration of Saints Ignatius and Francis Xavier] (1622) and Vincenzo Guiniggi's Ignatius arma mutans [Ignatius changing arms] (1622), to the plays about saint Hermenegild by Emanuele Tesauro (1621 in Latin; 1661 in Italian) and Sforza Pallavicino (1644). ${ }^{4}$

The Jesuits' use of theatre in the education of the young men who attended their schools in Italy and in Europe between the Renaissance and the nineteenth century became such a distinctive and successful trait of their programme of education that it influenced other religious orders devoted to the education of youth as well. The Salesians of Don Bosco, ${ }^{5}$ in particular, stand out for their use of theatre as part of their educational programme because it was directed towards both young men and women, in a tradition that started from their origins and continues even to today. Additionally, like the Jesuits, the Salesians also used the lives of saints in their educational theatre.

\section{The Salesian teatrino: A School of Sanctity}

A constant theme in all of Don Bosco's preaching to the young men in his oratory was that God willed the sanctification of everyone: "It is God's will that we all become saints, it is easy to become a saint, and there are great rewards in heaven for saints", he once famously said (Bosco 1878). ${ }^{6}$ That goal, he explained, was not difficult to reach: one need only "maintain constant and tranquil joy; complete one's daily duties towards God and studies; and enjoy regular recreation with the other boys" (Bosco 1878). ${ }^{7}$ One of the many ways in which the youth who attended Salesian schools and oratories would be supported in their aspiration to become saints was through theatre. "If the plays are judiciously chosen, theatre is a school of morality, of correct social behaviour and sometimes sanctity", Don Bosco once declared (Stagnoli 1967-1968, p. 103). He started involving in theatre the young men who belonged to his oratory as a way of occupying them while he was engaged for long hours in confessions. ${ }^{8}$ Theatre was part of his preventive system of education, ${ }^{9}$ as young people occupied in healthy pastimes such as rehearsing for or attending an educational play would have less occasion for mischief and sinning. Theatre, Don Bosco continued, "helps to develop the actors' minds and teaches them to express themselves easily and naturally. It gives pleasure to the boys who keep thinking about it for many days before and after the performance; it's a powerful tool to keep their minds busy. How many bad thoughts or words it removes, by concentrating on itself all attention and all conversations! Finally, it attracts many boys to our colleges, for, during the holidays our students talk to their parents, friends, and acquaintances about what happy places our houses are" (Stagnoli 1967-1968, p. 103).

Don Bosco called his educational theatre teatrino (little theatre) to distinguish it from the major theatre and its often non-educational characteristics. His teatrino was meant to

4 See Muneroni (2019) for an English translation of the play.

5 Giovanni Bosco (1815-1888) founded the Society of St Francis de Sales, commonly known as the Salesians of Don Bosco (SDB), for the education of boys and young men, especially from underprivileged classes. Together with Maria Domenica Mazzarello, he also founded the order of Figlie di Maria Ausiliatrice [Daughters of Mary Helper of Christians] (FMA) for the education of girls and young women. Don Bosco was canonized in 1934; Maria Mazzarello in 1951.

6 All translations from the Italian into English are mine.

7 The then Archibishop of Milan Dionigi Tettamanzi modified the last part of this famous quote as "always strive to do good to others" (Tettamanzi 2004).

See Lewicki (2012) for a study in English of the origins of Salesian theatre.

9 For an overview of Don Bosco's educational method, see Braido (1999). 
"entertain, educate, and instruct youth as much as possible from a moral point of view" (Stagnoli 1967-1968, p. 98), and therefore should avoid situations that might negatively affect the hearts of young people. There should be no "cruel, revengeful or immoral characters", "no duelling, no shooting, no violent threatening", and no language that was "ill-bred and vulgar" (Stagnoli 1967-1968, p. 152). Another non-written rule of Salesian theatre was that there should be no mixing of genders or cross-dressing. ${ }^{10}$

Moreover, in order that the works staged for and by Salesian students might be "judiciously chosen", by the end of the 19th century many Salesian priests and sisters began to author plays for groups of only young men or only young women, including many lives of the saints. Biesmans reports, for example: As the information on the date is given at the end of the sentence that the plays staged in the first Oratory of Valdocco at the end of the 19th century "dealt with the lives of such saints as St. Louis of France, St. Pancras, St. Mammes, and St. Cecilianus as an image of St. Cecilia" (Biesmans 1999, pp. 154-55). In the all-girls FMA oratory also in Torino Valdocco, between 1912 and 1921 are recorded several performances of plays on the lives of St Agnes, St Joan of Arc, as well as Sts Giusta and Rufina (Civitelli 2007, pp. 370-75). ${ }^{11}$

Theatre would continue to be one of the essential elements of Salesian schools and oratories throughout the first part of the 20th century and would resume with renewed enthusiasm after the end of WWII, with the hope that "calming and Christianising" plays might help heal "the tormented social anxiety of today's world" (Salvestrini 1949, p. 64).

\section{Saints and Mass Media in Post-WWII Italy}

Several scholars have remarked on the "widespread form of cultural interest in saints and sainthood evolving during the period 1945 to 1960" (Baaden 2014, p. 875). The Catholic Church in Italy did not hesitate to take advantage of media such as radio, cinema, TV, glossy magazines, and cartoons to rejuvenate the ancient genre of hagiography. ${ }^{12}$

The Catholic Church had long recognised the importance of the radio as a medium for spreading its message, seeing it almost as an extension of the pulpit (Caliò and Rusconi 2008 , p. 6). For the holy year of 1950, the Vatican broadcast a series of radio programs on the lives of twelve important saints (apostles, evangelists, doctors of the church, founders of orders) considering them a "testimony of faith and eternal source of moral education" (Anania 2008, p. 21) for the listeners.

Glossy magazines such as Oggi or Gente, on the other hand, devoted their pages not so much to those already canonised as to those famous individuals popularly considered saints, such as Don Orione (1872-1940, canonized in 2004) or Padre Pio (1887-1968, canonized in 2002). Such a peculiar form of hagiography, comments Tommaso Caliò, moved away from erudition toward current affairs or even gossip, reporting on wondrous events as they were happening but without proper investigation (Caliò 2008, p. 30). Other magazines directed to younger audiences, moreover, published episodes on the lives of the saints in cartoon form, with an emphasis on the devotional, educational or even adventurous aspects of their stories (Gorla 2008, p. 96). ${ }^{13}$ In the 1960s, the weekly Catholic magazine Famiglia

10 Cervera (1976) reports an undocumented oral anecdote that refers to Don Bosco's attendance at a school staging of a classical play in which young men had dressed up to play the female roles. Don Bosco, according to this story, realised the risks of continuing such a practice and recommended single-gender or gender-neutral plays.

11 In the inter-war years, staged plays included the lives of more recent martyrs. For example, a work which would have served to both celebrate Salesian martyrdom and strengthen the anti-Bolshevik sentiment of the time is Fiori di martiri ossia fede intrepida [Flowers of martyrs or fearless faith] by Sr. Maria Emma Acchiappati (1888-1970), see Acchiappati (1939). The protagonists of the play, set in Barcelona in July 1936, are Salesian-educated young women who witness the destruction of their school, and hear about the death of Salesian sisters Sr Moreno and Sr Amparo. Later in the play, they themselves will refuse to denounce their faith and will be martyred offstage. The play ends not with the young women's death, but rather a vision of Maria Mazzarello, surrounded by the two Salesian martyrs and the three young women, with angels among the clouds.

12 Theatre is conspicuously absent from this list. A memorable Rappresentazione di Santa Uliva, directed by Jacques Copeau, with music by Ildebrando Pizzetti, was staged in Florence in 1933 but remained a quite unique theatrical event. A few saints appear as comic characters in 1950s comedies such as Eduardo de Filippo's De Pretore Vincenzo (1957), and Giovanni Gigliozzi's Santi in soffitta (1959).

13 An example is the life of St. Francis Xavier in cartoon form, entitled Il pirata di Dio [God's pirate] (Gorla 2008, p. 97). 
Cristiana also published lives of the saints in the format of fotoromanzo, or photonovel (Bonifazio 2020, pp. 127-36).

Although TV miniseries on the lives of the saints would not proliferate until the late 1980s (Anania 2008, pp. 126-29), already in 1966 the Italian national TV company RAI broadcast a miniseries called Francesco d'Assisi, directed by Liliana Cavani. ${ }^{14}$ Additionally, of course, the lives of the saints were also presented after the end of WWII in such films as Oreste Paolella's Caterina da Siena (1947) and Io, Caterina [I, Catherine] (1957); Augusto Genina's Cielo sulla palude [Heaven over the Marshes] (1949) on Maria Goretti's story; Roberto Rossellini's Francesco, giullare di Dio [Francis, God's Jester-better known in English as The Flowers of St. Francis] (1950) and Giovanna d'Arco al rogo [Joan of Arc at the Stake] (1954); and Antonio Leonviola's Il suo più grande amore [Her greatest love] (1956) on St. Rita of Cascia. While not exactly the life of a saint, Giuseppe Rolando's Appuntamento in paradiso [Appointment in Heaven] (1960) chose as its protagonist a boy from the oratory who tries to imitate the example of Domenico Savio by saving his friends.

James Baaden explains that the interest in saints, already heightened in the interwar years by the canonization of such popular figures as Joan d'Arc (in 1920), Thérèse of Lisieux (1925), Bernadette Soubirous (1933), Don Bosco (1934) and Thomas More (1935), acquired new meaning due to the feelings of "mass bereavement and ethical disorientation" felt by most of the European population in the years immediately following the end of WWII (Baaden 2014, p. 882). Moreover, in Italy at the time, the Catholic church was trying to restore its influence and reduce that of the Communist party. ${ }^{15}$ Thus, "it was likely not a coincidence", explains Baaden, "that Pius XII's first major public act after the end of hostilities had been to canonise an Italian-born representative of North America, Mother Cabrini, in the summer of 1946" (Baaden 2014, p. 888). Calio adds that in the post-war years, Catholic institutions also needed to propose saintly figures to set against those who were considered lay martyrs of the Fascist regime and the Resistance (Caliò 2008, pp. 112-13). Of particular importance was the 1950 canonization of Maria Goretti, ${ }^{16}$ an event which the Church endeavoured to make "accessible, memorable and photogenic" (Baaden 2014, p. 888), attended by hundreds of thousands of people. Giovanna Grignaffini also notes a proliferation of films based on the lives of female saints, virgins and martyrs between 1943 and 1960 and ascribes it both to specific historical events (such as the already mentioned canonization of Maria Goretti, and the celebration of the first Marian year in 1954) and to the general importance of female characters in the post-war Italian cinema as symbols of the process of moral, cultural, and economic rebirth of the country (Grignaffini 1994, pp. 524-27).

Despite the post-war use of film to portray the lives of the saints, Catholic centres for youth tended to privilege theatre over cinema (Caimi 1988, pp. 212-13). The Salesians, in particular, defined cinema as "the gravest danger for our spirit, because it dulls and extinguishes the refinement and modesty which Don Bosco left us as our characteristics" (Caimi 1988, p. 219). In their desire to renew and strengthen educational theatre, in the post-war years the Salesians started the publication of two new magazines devoted to single gender-theatre: Teatro dei giovani [Young men's theatre] and Teatro delle giovani [Young women's theatre]. Although they contained different plays, the two magazines shared several editorials and articles.

While other Catholic theatre publications which emerged or were revamped in the mid-1940s moved away from staging the lives of saints and martyrs, considering them old-fashioned and obsolete (Cavallaro 2017, pp. 138-39), the Salesians still preferred to stage the lives of the saints instead of dealing with other topics that they considered potentially dangerous. Although theatre is life copied onstage, an editorial in Teatro delle

14 Television miniseries and films on the lives of the saints have continued well into the twenty-first century. See Perugini (2011) for recent television series on popes, priests, nuns and other exemplary religious figures.

15 Caliò (2008, p. 31) also states that the "miraculous" events reported in glossy magazines would often also cause the conversion of communists.

16 On the importance of the figure of Maria Goretti as a symbol of sexual purity in the post-war years, see Bennett (2011). Goretti (2012) on the other hand, discusses the figure of Maria Goretti as a role model for communist girls. 
giovani explained, it should not indiscriminately include all of life, complete with its ugliness, but only "that life which is beautiful and good, that which is lived under the eyes of God" ("L'educazione" 1950, p. 2). Thus, many of the plays published in Teatro dei giovani and Teatro delle giovani are based on episodes from the lives of the saints, especially the lives of the two founders of the orders, Don Bosco and Maria Mazzarello. ${ }^{17}$ In this article I'm interested in particular in plays that stage the lives of young saints, with precise role models for young men and women on the stage and in the audience. Although the lives of many young saints were chosen for educational plays-for example, the Roman martyrs Bibiana (Pesci 1950), Emerenziana (Pesci 1956) and Tarcisio (Garro 1949)- there is no doubt that the most popular were Agnes for young women, and Domenico Savio for young men, with several plays for each published in the years between 1950 and 1965.

\section{The St Agnes Plays Published in Teatro delle giovani}

In a 1965 Salesian sketch set in Heaven, St Agnes appears as part of an all-Salesian group preparing for a major celebration in honour of Don Bosco: Maria Mazzarello, Sister Teresa Valsè, ${ }^{18}$ Mother Morano, ${ }^{19}$ and Laura Vicuña. ${ }^{20}$ Agnes wishes to join them, saying: "I hope that at least today you will welcome little saint Agnes among your group!", to which Mother Morano replies: “But of course! Aren't you one of the dearest patrons of our youth?" (Fornara 1965, p. 111).

The Roman virgin martyr Saint Agnes has, in fact, often been used as an example of chaste youth in Salesian schools and oratories for girls and young women. Special prayers to the saint mentioned the "many dangers, numerous seductions, strong passions, [and] insidious worldly deceptions" that may lead a young woman astray, and petitioned the virgin martyr to allow the young woman "to always keep a pure heart, a chaste body, mortified senses and never allow in [her] mind thoughts or desires that may trouble the peace of [her] conscience" (Maccono 1910, pp. 146-47). ${ }^{21}$ FMA schools and centres often take her name, solemnly celebrating her feast day, January 21, often with a recital of a play with her as the main character ("Siamo Figlie di Maria Ausiliatrice" 2019).

The traditional accounts of the life of St Agnes report that a powerful man, the prefect's son, wanted to marry her. When she refused - she wanted only Jesus as her spouse-Agnes was revealed as a Christian and exposed in a brothel. Miraculously, however, no one was able to touch her. Other versions say she was dragged naked through the streets, but, again miraculously, her hair grew so much it covered her from view. In the end, she was tied to the stake, but when - miraculously—-the flames did not touch her, she had to be killed by the sword ("Saint Agnes" n.d.a; "Saint Agnes" n.d.b). It's not hard to see that such an account of the life and martyrdom of St Agnes would not agree with the main tenets of Salesian theatre, that is, that no violence be presented on stage and that no member of the single-gender cast should cross-dress. Given the brutality of her martyrdom and yet the rules of Salesian teatrino, I have chosen three exemplar Salesian plays on the life of St Agnes to see what issues they did highlight and how they tackled the problem of male characters and violence.

17 Among the many plays on Don Bosco, see Bini (1958). See Pesci (1951) for the most significant play on Maria Cavallaro (2011, pp. 32-34) for a discussion of that play.

18 FMA sister (1878-1910), declared venerable in 1982.

19 FMA sister (1847-1908), declared blessed in 1994.

20 Salesian educated teenager (1891-1904), beatified in 1988.

21 While at the time the handbook containing these prayers was written (1910), it would have made perfect sense to choose saint Agnes, one may wonder why during the 1950s and '60s the Salesians did not make more use of Laura Vicuña or Maria Goretti as more contemporary symbols of female purity. My guess is that in both cases the lives of those saintly young women would have needed reference to their attempted rape, and so would have gone against the tenet of Salesian theatre to avoid or even suggest any form of violence on stage. In the one play based on the life of Salesian-educated Laura Vicuña published in the post-war years, Caterina Pesci's Per te, mamma! [For you, mom!] (Pesci 1961), emphasis is given to Laura's sacrifice to save her mother's soul rather than on her experience of abuse. See Cavallaro (2011, pp. 34-36) for an analysis of the play. 
Caterina Pesci's ${ }^{22}$ Il velo insanguinato [The blood-stained veil] (1954) looks at three moments in the life of the young saint. The stage directions instruct the actor playing the role of Agnes to wear a white dress and a beautiful white veil throughout all three acts. ${ }^{23}$ During the play, in fact, Agnes refers to her white veil as the symbol of her chosen virginity, protection against evil, and the shroud of her martyrdom.

The first act stages Agnes' reaction soon after she tells her sister about being accosted by Procopio, the son of the Prefect, and her realization that her life is now in danger. Nevertheless, she remains firm in her resolution: "this veil [ ... ] is the symbol of my consecration to Christ. I don't want a single human eye to so much as glance at my face. Only the angels can cast their eyes on me, little spouse of Jesus [ . . ] I want only to love Christ and his angels" (Pesci 1954a, p. 15).

The second act is set in the country villa where Agnes repaired to escape Procopio's advances. He has found her there, however, and only her loyal African slave Getulia has managed to protect her. Her jealous friend Macrina accuses her of having bewitched Procopio and learns of her Christian faith. Still, Agnes prays that no stain tarnish her veil other than the blood of martyrdom. Finally, in the last act, Agnes awaits her execution in jail. She again calls the veil her "only wealth, white as faith, immaculate as the virginity that [she has] loved more than [her] life" (Pesci 1954a, p. 36). To Macrina, who wishes to own Agnes' veil so that she too might have "that beauty made of light [ ... ] of endless, mysterious happiness" (Pesci 1954a, p. 36), Agnes' choice will remain mystifying. After her slave is killed, Agnes will also be beheaded (all offstage, of course); with her last words she prays for the enlightenment of the pagan friend who caused her death.

As in many other educational plays for young women, so too in Pesci's Il velo insanguinato the protagonist's encounter with a young man is reported in conversation with a female relative or friend; there is no need for his physical presence on stage. However, while in other non-hagiographic plays such an encounter might be the source of much happiness, heart throbs or gossip, here it causes only anguish and fear in the protagonist, who, above all, wants to preserve her virginity. She calls the prefect's son "a child of darkness" - his dark eyes "an abyss where flames of corruption blaze" (Pesci 1954a, p. 19) - "a pasture of iniquity [ ... ] an ember of hell", even "the devil himself" (Pesci 1954a, pp. 23-24). Agnes' slave also calls him a "child of Satan" (Pesci 1954a, p. 30) adding that "his body and soul are rotten with vices" (Pesci 1954a, p. 27). ${ }^{24}$ By associating the prefect's son with the devil, the play suggests that the spectators are witnessing not only the story of young Agnes, but an episode in the eternal fight between good and evil, between Christ and the antichrist-a struggle that believers know will end with the victory of Christ. Pesci uses the character of the recent convert slave Getulia to remind the spectators that even in the darkest hour, one should remember that light will prevail:

GETULIA-How can an evil sinner like Procopio sentence you to death, you who are as beautiful as the morning star and purer than the sun?

AGNES-(gently) How? Because this is Satan's hour, the hour in which the Church was crucified, as in that holy Friday Jesus was crucified ... [ ... ] But then the Master triumphantly rose, and the Church will rise again. She will emerge in the light; she will triumph through the centuries, her roots firmly anchored in Christ's blood and in our blood. (Pesci 1954a, p. 33)

22 FMA sister (1906-1970), author of many plays and novels. See Ossi (1990) for a 2-volume biography in Italian; Cavallaro (2017, pp. 228-29) for a short biographical note in English.

23 In a short dialogue published immediately after this play, Pesci herself makes fun of the difference between the ideal costumes and scenes her historical plays require and the reality of educational theatre. In Per la festa di S. Agnese [For S. Agnes' day] (1954b), the four girl protagonists search in vain for a long white tunic, pink cape, palm tree branch and a little lamb to be able to have St Agnes appear on stage on her feast day. But all they can come up with is a long white nightdress, a pink bed cover, a branch of a Christmas tree-St Agnes day is January 21, so not long after the end of Christmas celebrations - and a small white rug to represent a lamb. By the end of the dialogue, the protagonists will decide to focus their performance on the Virgin Mary instead, 1954 being a Marian year, having on stage a bunch of flowers with inspirational messages in front of a statue of Mary. St Agnes, they say, "will be very happy to give her place to the Queen of virgins and martyrs. In fact, she would probably feel confused if we dared ask her to come down from Heaven in this Marian year ... " (Pesci 1954b, p. 41).

24 If the young man is compared to the devil, the jealous friend Macrina is compared to a snake (Pesci 1954a, pp. 25, 28). 
Agnes' blood, highlighted in the play's melodramatic title, is thus associated with the blood of Christ. The same title also serves as a metonymical representation of Agnes' final martyrdom - a martyrdom that will happen after the play ends and will bring salvation to others. A sequel to this play, Sulle sue tracce [Following her footsteps] (1956), also by Pesci, shows that both Procopio and Macrina have converted to Christianity thanks to Agnes' example of faith.

A few years after the publication of Pesci's Il velo insanguinato, the play Il fiore e la croce [The flower and the cross] by F. M. A. (1956) ${ }^{25}$ borrows the plot and character of Fabiola, the fictional Roman noblewoman created in 1854 by Nicholas Wiseman, as a background for St Agnes' story ${ }^{26}$ In fact, some of the characters and dialogues are taken almost literally from Fabiola. In Act 1, for example, which draws from chapters IV and V of the novel, Fabiola appears as a rich and spoiled young Roman woman who does not hesitate to strike her slaves when irritated. As in Wiseman's Fabiola, Agnes is Fabiola's Christian younger cousin, a helper of the poor and slaves. In the second act, Agnes learns that the prefect's son would like to marry her, but she refuses, saying she is already engaged. ${ }^{27}$ By the third act, Agnes will willing go to her martyrdom, having refused to escape from jail to marry the prefect's son. ${ }^{28}$ Agnes' firm faith moves Fabiola, who promises Agnes, as she steps toward martyrdom, to learn about the Christian faith. In the finale, images of the play's title-a lily, the symbol of Agnes' purity, and a cross-are projected onto the stage backdrop.

In the same way that the prefect's son's character and marriage offer are barely mentioned in act 2, and are not the cause of the conflict (it is not him who reports Agnes as a Christian), so too Agnes' punishment is only obliquely mentioned in act 3:

AFRA: if you don't relent by tomorrow, what you fear more than death, what happened to you the day before yesterday, will happen to you again. And it'll destroy your illusions for ever.

AGNES: Just like the other day, I'll never fear anything, because the whole of me, body and soul, belongs to Christ. But rest assured: An angel has been watching over me. He'll save the bride of the Lord. ${ }^{29}$ (F. M. A. 1956, p. 49)

Unlike Pesci's and F. M. A.'s plays, Laura Toselli's La cintura di Agnese [Agnes' belt] (1959) begins on a very joyful tone, as Agnes, her foster sister Emerenziana, and her friends prepare to celebrate Agnes' birthday with a picnic and dance. As Agnes looks at her laughing friends, she is delighted to have "sunshine, flowers, smiles and the Lord's grace" as part of her thirteenth birthday celebration (Toselli 1959, p. 42). What Agnes ignores is that her new African slave Maura has innocently given information to the prefect's son Crispo Marco Procopio, who is interested in her. ${ }^{30}$ In act 2, Agnes reaffirms her intention to become a bride of Christ, refuses gifts sent by Procopio through Maura, and wishes to

25 F. M. A. are the initials of the order, Figlie di Maria Ausiliatrice. It was not uncommon at the time for Salesian sisters to have their plays published anonymously or with a pseudonym.

26 The novel was made even more popular in Italy by the 1949 homonymous film directed by Alessandro Blasetti which, however, does not include St Agnes as a character.

27 For this scene, Wiseman's novel had the character of Fulvius directly proposing to Agnes. The Salesian play has a character named Fulvia talking about the prefect's son's interest in Agnes.

28 In the novel, it was Fulvius himself who came to the jail to offer Agnes freedom if she married him. In the play, it is the avid African slave Afra, the same one who turned Agnes in for being a Christian, who makes the same offer on behalf of the prefect's son.

29 These words are taken almost literally from chapter XXIX of Wiseman's Fabiola, which also explains that it will not describe her tortures in detail: "Over the first part of the martyr's trials we cast a veil of silence, though ancient Fathers, and the Church in her offices, dwell upon it, as doubling her crown. Suffice it to say, that her angel protected her from harm; and that the purity of her presence converted a den of infamy into a holy and lovely sanctuary" (Wiseman 1885, chapter XXIX).

30 Maura, introduced in the list of characters only as "black woman" (Toselli 1959, p. 40) is used as both plot device (she needs to be the one who acts as go-between for Procopio, but not the one who betrays Agnes, as she is well treated by the family and has no reason to) and comic relief. She shows both the characteristics of the 'country maid' who looks at everything in awe and admiration, of the 'magpie' who appreciates anything shiny and sweet, and at the same time of the ignorant, exotic, pagan African, who speaks without conjugating verbs and needs to be taught about the Christian faith as if she were a very young child. Her characterization would cause unease in our time for being quite racist. 
prepare for the ceremony-the belt in the title will be part of her bridal wear. ${ }^{31}$ In act 3 we see Agnes in jail—another slave, Egle, has denounced her as Christian for money. Agnes, however, forgives the repentant slave and sends her to Emerenziana to be instructed in the faith. Here too Agnes could be saved, by either sacrificing to Vesta or marrying Procopio, but she remains firm in her choice of martyrdom. She prays to her guardian angel to watch over her and protect and preserve her innocence. As in many other Salesian plays in which angels and devils are part of the characters onstage (Cavallaro 2013), here an angel, standing next to Agnes, reassures her: "Listen to me and don't be afraid: like a lamb among wolves God will let you be tempted, beaten, led to a sinful place [ ... ]. A stake will be prepared for you, but the flames will not touch you, for I will be next to you to make them harmless" (Toselli 1959, pp. 46-47). ${ }^{32}$ )

As in Il fiore e la croce, so too in La cintura di Agnese, Procopio has been reduced to a minor role. Only his voice is heard in act 1 asking a few questions as to the identity of Agnes (presumably, girls were not precluded from faking a man's voice offstage as they were from dressing up as a man onstage); he sends gifts to Agnes in act 2; and in act 3 we learn from a family friend that he will let Agnes practice her Christian faith if she only agrees to marry him - very much unlike the devilish character of Pesci's Il velo insanguinato. There are other aspects of Toselli's play, however, which stand out even more for the modern reader. The first is the colloquial language of the play-quite different from the solemn tone of Pesci's play - with conversations ranging from the food prepared for the birthday party to plants and flowers. This colloquial, contemporary language may have suggested to the audience several comparisons between Agnes' story and relatively recent Italian history. One such moment of the play calls for attention as it is not necessary for the development of the plot. In act 2, Roman matron Stefania and her daughter Emilia visit Aurelia, Agnes' mother. While the two girls are sent outside to play, the pagan Stefania warns Aurelia of a new persecution against the Christians, which means she will not allow Emilia to have further contact with Agnes. As this play was written about 20 years after the proclamation of the racial laws in Italy (1938), it is not hard to associate Stefania with one of the many Italians who were friends with Italian Jews but refused any connection with them for fear of being tainted by association.

Furthermore, when Stefania reappears in act 3, together with another friend Flavia, to visit Agnes in jail, they come "to act as if we were [her] mother" (Toselli 1959, p. 47) asking her to marry Procopio or sacrifice to the Roman gods: "Do it for your mother who is crying for you! For your father who is crazy with grief! For your friends who are mourning your fate!" (Toselli 1959, p. 48). Once again, the modern, colloquial language of the play brings to mind similar words that would have been used in war time to convince people condemned to death to save themselves, by naming names, by feigning allegiance to the Fascist regime. If Pesci associated Agnes' martyrdom with the eternal fight between good and evil, Toselli seems to suggest that more recent evils have been causing betrayal and martyrdom in our times.

In addition to the plays by Pesci, Toselli, and the anonymous FMA author which look at moments of St Agnes' life, two more plays published in Teatro delle giovani make references to St Agnes, but are set in modern times: Elisa Duranti's Agnese (1953), and Il processo di Santa Agnese [St Agnes' trial] (1963). ${ }^{33}$

In Agnese, the young protagonist Anna is studying Petrarch's poem "Vergine bella, che di sol vestita" [Lovely Virgin, clothed with the sun], in which the poet addresses the Virgin Mary, revealing a soul divided between earthly loves and spiritual aspirations. Anna

31 This is in fact the only time that her belt, which has so much prominence in the title, is mentioned in the play. The verse in Jeremiah 2:32 which in English is translated as "Does a young woman forget her jewellery, a bride her wedding ornaments?" refers in Italian to the bride's belt, which, like a priest's fascia or cincture, is a traditional symbol of purity. The vesting prayer used by priests when putting on such vestment says: "Gird me, $\mathrm{O}$ Lord, with the cincture of purity, and quench in my heart the fire of concupiscence, that the virtue of continence and chastity may abide in me" ("These vesting prayers before Mass remind priests of their unique vocation" 2018).

32 At this point Agnes is worried that she may not die, as she wishes for martyrdom, as only through martyrdom will she "get to see and possess the God that I love and that I yearn for". The angel reassures her that her wish will be granted, as she will be decapitated (Toselli 1959, p. 47).

33 FMA sister (1888-1977). See (Cavallaro 2017, p. 225) for a short biographical note on Duranti. 
at first admits to sharing the poet's feeling- "such an inner struggle, as if one had two souls ... I understand Petrarch, as I too ... " (Duranti 1953, p. 61). It is St Agnes' day and Anna, looking at a statue of the saint, admits to having had aspirations of "an ideal of beauty, of sanctity" (Duranti 1953, p. 61). However, then she claims that in modern times it is impossible to emulate Agnes. In a dream, however, St Agnes herself proves Anna wrong by pointing to Laura Vicuña, who gave her life for the conversion of her mother, and Maria Goretti, who preferred to surrender her life rather than her virginity-two modern girls who, like Agnes, went to their deaths pure. However, other Agneses of the 20th century give their life in a different way, the saint explains: "they leave their families, their dearest things; they consecrate their lives in schools, hospitals, missions" (Duranti 1953, p. 64). The dream convinces Anna, who awakes ready to hear Jesus' call and follow in Agnes' footsteps.

Duranti's later Il processo di Santa Agnese is also set in contemporary times. The short play, meant to be staged on the saint's feast day, explicitly draws on Diego Fabbri's 1955 Processo a Gesù [Jesus' trial]. As in Fabbri's play, the characters on stage introduce themselves to the audience, explaining that four of them are lawyers, and one will be the judge. This trial, the judge explains, is not meant to support Agnes' conviction, but to find out if there had been extenuating circumstances to justify the decisions of those who condemned her. The lawyers in fact list the Christian threat to Roman culture, Procopio's love for Agnes, and Procopio's father (the prefect)'s love for his son. Thus, the trial appears to be moving toward an absolution of the Romans, until the spectators realise that the actual trial taking place is not so much about the saint's death as about their own behaviour. The first lawyer explains it this way: "We wanted all of you —and ourselves— to be ashamed of being so inconsistent with our Christian faith .... We wanted all of you and us to decide to be like St Agnes, real Christians ... " (Duranti 1963, p. 79). The play ends with the spectators' voices promising to follow St Agnes, to be strong in their resistance to temptations and threats.

Both of these plays by Duranti, in other words, avoid the problem of how to present Agnes' martyrdom on stage by not actually staging her life. In Il processo di sant'Agnese, the judge briefly refers to the tortures she was submitted to when introducing the topic of the trial, emphasizing not so much the suffering itself, but rather God's miraculous interventions to protect her purity. In Agnese, on the other hand, the choices referred to (not staged) are those of two other contemporary young women, one to give her life for the benefit of others (Laura Vicuña), one to preserve her purity (Maria Goretti)—again, without any mention of abuse or attempted rape.

However, more importantly, the two plays use the characters of St Agnes as a role model for contemporary teenagers not by presenting her life on stage, but by directing young women to follow in her footsteps. While the 1953 play suggests what to do-devote your life to the service of others-Il processo di sant'Agnese instructs the audience instead as to what not to do, and thus, like Agnes, "to be strong in the face of evil temptations, enticements of passion, and threats from the enemies who would like to separate us from Christ" (Duranti 1963, p. 79). The 1963 play explicitly asks its viewers to renounce styles of fashion or forms of entertainment condemned by the church, and to stop giving the excuse of peer pressure to skip Mass or listen to corrupting words. While in the plays devoted to St Agnes' life by Pesci, Toselli and others, the character of Agnes was the protagonist and the audience witnessed the conversions that the saint's example created in her times, in Duranti's plays the saint herself is presented either only as a statue coming to life in a dream, or is not on stage at all. ${ }^{34}$ In the end, in both plays Duranti intends to convert the audience itself, to produce a change of behaviour in line with contemporary times.

$34 \quad$ Il processo di sant'Agnese ends as the curtains closes on the judge asking St Agnes for a blessing; in an alternative ending, a young woman dressed as the saint steps on a pedestal and the five characters kneel before her. 
This same style of hagiographic plays-in which the past life of a saint is staged or their influence is still felt in contemporary times-has also been used in many plays for boys concerning Domenico Savio.

\section{The Domenico Savio Plays Published in Teatro dei giovani}

Domenico Savio (1842-1857) was about 12 years old when he met Don Bosco and joined his oratory. Due to his excellent behaviour, good school results, and desire for consecrated life, he had already caught the attention of the teachers and priests who had met him and recommended him for early first communion and further studies. With Don Bosco's support, Domenico developed his wish to live a saintly life. The first recommendation he received was to seek the salvation of others-thus, he worked with both schoolmates and strangers to make sure they avoided blasphemy, paid respect to the Holy Sacrament, went regularly to confession, and avoided fighting and occasions for impure thought and actions. When talking to a new student at the oratory, Domenico Savio famously summarised how Don Bosco's students reached sanctity: "Here holiness consists in being very cheerful. We strive to avoid $\sin [\ldots]$, to complete our duties, and perform the practices of piety" Bosco 1878, chapter XVIII). Having died at a very young age, Domenico Savio was the first teenager to be canonised without being a martyr.

It was Don Bosco himself who contributed to making Domenico's life widely known by writing his biography. ${ }^{35}$ The educational purpose of the work is explicit from the beginning, as Don Bosco, addressing his young readers, offers Domenico Savio as a model to imitate: "But for now try to draw profit from what I am going to describe; say in your heart what St. Augustine used to say: si ille, cur non ego? If a schoolmate, of my age, in the same place, exposed to the same or even greater dangers, found a way to remain a faithful follower of Jesus Christ, why can't I do the same?" (Bosco 1878, address to the readers). ${ }^{36}$ However, according to Arthur J Lenti, Don Bosco's biography of Domenico Savio "does not merely fulfil an edifying and educational purpose. [ . . . ] It tells a story in which Savio is presented both as having practiced virtue in a heroic degree and reached the heights of sanctity, as well as having been favoured by God with extraordinary, miraculous and mystical experiences. This is hagiography" (Lenti 2001, p. 49). Thus, Lenti concludes, Don Bosco's biography of Domenico Savio constituted the greatest testimony of the teenager's heroic virtues, hence allowing the young man to be proclaimed venerable (in 1933), blessed (in 1950) and saint (in 1954). At the same time, adds Pietro Stella, through the biography the oratory itself would come to be seen not so much as a chaotic conglomeration of dangerous youth but, on the contrary, as the soil from which sanctity could sprout, grow and flourish (Stella 2005, p. 15).

Don Bosco's biography of Domenico Savio-written by the Salesian order's founder on the life of a Salesian-educated teenager-in addition to occupying a special place in the upbringing of many Catholic young men, ${ }^{37}$ also occupies a central place in the plays on

35 The first edition dates to 1859 , only two years after Domenico's death; the 5 th edition, of 1878 , is considered the definitive one, as it was the last one edited by don Bosco himself. See Bosco (1914) for an English version of Savio's biography.

36 See also (Bosco 1878, chapter XXVII): "Friendly reader, as you were kind enough to read about this virtuous young man, I wish you would join me in coming to a conclusion that may be of great usefulness to me, to you and to all those who may happen to read this little book: that we resolve to try to imitate young Savio in those virtues that are compatible with our situations".

37 Stella (2005, p. 11) reports that even the future popes Pius X and Benedict XV read it as adolescents. In a later article, Stella notes that the biography does not include the presence of women, not even Savio's little sisters or the mother and sister of don Bosco who surely did have an important presence in the oratory's daily life. Such removal of female characters, asserts Stella, is an indication that the biography was aimed at those who attended all-male schools, oratories or seminaries (Stella 2009, p. 165). A large image of Domenico Savio appears on the wall of the Catholic school attended by the protagonist of Federico Fellini's film $8 \frac{1}{2}$ (1963). But Savio's biography also went beyond Italy. Famous American film critic Roger Ebert recounts that he was "inflamed" by a biography of Savio and took his name as a confirmation name (Ebert 2010). North American scholars Donald L. Boisvert and Dominic Wetzel have shared their memories of having Domenico Savio presented as a role model of purity while they were growing up in Catholic environments. "St. Dominic Savio walked through the city with his eyes turned towards heaven, to avoid looking at girls, to prevent impure thoughts. St. Dominic Savio slept with his hands crossed over his chest so as not to be 'tempted' at night", Wetzel was often told (Wetzel 2014, p. 67). Domenico Savio was a "kind of superhero for me. He was brave, and strong, and good, and kind", Boisvert states (Boisvert 2018, p. 257); but it was his purity that was mostly extolled among the youth: "His statue and image looked down serenely from Salesian walls, overseeing the preservation of manly Salesian virtues, especially that of youthful purity. This purity was his prized treasure, his true mark of greatness, his lasting legacy" (Boisvert 2015, p. 188). 
Domenico Savio as well. All the plays published in Teatro dei giovani that stage Savio's life draw on episodes reported in the biography. The plays set in contemporary time, on the other hand, show how the biography still positively affected its readers, more than half a century after its publication.

In March 1950, immediately after Domenico Savio's beatification, a special issue of Teatro dei giovani included several pieces devoted to the newly beatified. ${ }^{38}$ One play, Domenico Savio — dai campi alle stelle [Domenico Savio-from the fields to the stars] by Ivo da Sanfelice, re-enacts five pivotal moments in the short life of the saint: the day he received his first communion at age 7 , while the existing guidelines suggested age 12; the day he met and made an impression on Don Bosco, who accepted him into his school; several times in which he positively influenced his schoolmates, by preventing them from fighting or looking at scandalous publications, or convincing them to join him for confession; the moment of his death; and finally his heavenly apparition to Don Bosco. Don Bosco's concluding words indicate the purpose for the representation: "Savio! You are saint! [ ... ] The whole world is exulting and rejoicing ... Our young people have found their role model" (da Sanfelice 1950, p. 43).

In his introduction to the piece, the author explained that he wanted the play to have a modern tone, devoid of monotony or oratorial declamations; for that reason he chose those episodes from the life of the young saint that would allow for lively dialogue and movement (da Sanfelice 1950, p. 25). In each of the five scenes, in fact, most of the conversations belong to other characters: the sexton and priest who witness Domenico's early examples of saintly behaviour; boys and teens who are friends with Domenico and while playing report stories of his positive influence over them; and of course, Don Bosco, who is portrayed as a good father to them all. Moreover, while the words attributed to Don Bosco and Domenico Savio draw from his biography, the other characters make jokes, use colourful language and in general provide a background of normality to Domenico's saintly life.

The mixture of normal life and Domenico Savio's exceptional behaviour comes to even greater light in the 1952 play L'angelo in portineria [The angel at the janitor's quarter] by T. $\mathrm{M}$. Vettori. As the title summarizes, the play uses the busy setting of the janitor's quarters to show the variety of people coming and going through Don Bosco's oratory: parents, children, policemen - even repenting petty criminals. The angel is Domenico Savio, who manages to affect positively the life of every person he encounters. The dialogues and the scenes refer once again to several well-known episodes of his life-how he stopped schoolmates from fighting, convinced others to go to confession, encouraged a man in the street to kneel before the Eucharist, or how he kept stones in his bed as corporal punishment-as well as the saintly way in which he accepted death at such a young age. Some scenes, however, are unique to Vettori. The play, for instance, shows how Savio's example of non-violent and forgiving behaviour converted a new schoolmate, and then the schoolmate's father-thus highlighting his work for the salvation of others, which Don Bosco had recommended as the first step toward sanctity. 39 "Domenico Savio gains more souls by playing games than a preacher preaching the six weeks of Lent" (Vettori 1952, p. 25), comments the apparently grouchy janitor, butt of many jokes by the boisterous boys of the oratory, but, like all other characters, convinced of the sanctity of young Domenico.

In 1957, on the centenary of Savio's death, Teatro dei giovani published episodes of the life of the young saint meant for the radio. Ragazzo santo [Holy young man] by Salesian priest Ersilio Renoglio stages the well-known moments when the young Savio convinces an adult man to kneel before the Holy Sacrament; starts a group called "The Immaculate Conception Sodality"; tears an inappropriate magazine to pieces; offers his coat to a mate; and finally dies, but then appears to Don Bosco in a dream. The speaker's voice summarizes the message of the play: "His life was short, but in a short time he did amazing things.

38 Theatre works on Domenico Savio had appeared even earlier; for example, Castellino (1920) and Marescalchi (1921).

39 Don Bosco is often mentioned in this play but does not appear in it. 
Additionally, today more than ever, young people from all over the world look at the holy adolescent and listen to his message. Domenico lives again, as an example of a spiritually strong and generous youth. His name, sung in every language, resounds like a divine message to the earth" (Renoglio 1957, p. 61). ${ }^{40}$

As in the case of St Agnes, in addition to purely biographical plays, other works published in Teatro dei giovani set in the present look at the influence that Domenico Savio can have on today's youth—and adults. La colomba nel sole [The dove in the sun] (1950) by Francesca Sangiorgio, ${ }^{41}$ for example, takes place in less than $24 \mathrm{~h}$. Mr Aloisi celebrates his 80th birthday surrounded by children and grandchildren, who praise him for having accumulated fortune and fame. The youngest of his grandchildren, Cesare, however, asks him instead if he has been happy and lends him the book he is reading: Don Bosco's biography of Domenico Savio. That night Mr Aloisi realizes that what he has strived to obtain during his 80 years of life is nothing compared to what Domenico Savio had aimed for from the beginning of his young life. The following morning Aloisi seems intent on changing his life, making the ethical choice even when it's not the most profitable, assisting his employees, instructing that a church be built where his employees will be able to celebrate Mass together, and finally agreeing to support the cinematographical ambitions of a grandchild only if the topic of his first film be on the life of Domenico Savio. The young saint makes a brief apparition in each of the two acts, but his lines are not nearly as powerful as the doubts that torment Aloisi in his dark night of the soul, or the calm certitude that Cesare expresses in the power of Domenico Savio to convert humanity.

The play does not imply that Mr Aloisi has in fact managed to read Savio's biography. In addition to a few details listed by Cesare-Savio's young death, his wish to die rather than sin, his willingness to suffer on behalf of others-Mr Aloisi is impressed with the image of the young saint on the book's cover, which is sufficient to cause him to wish to change his life. ${ }^{42}$ It is to that image that he tentatively prays, and it is that same image that he wants to have hung on the walls, next to the crucifix and the Virgin Mary, and it is the image of Domenico Savio that he also wants to have brought on the screen, to spread the model of his life. ${ }^{43}$ While, because of his age, Domenico Savio had been considered an appropriate role model for youth, this play suggests that the recently blessed young man can also affect the lives of those who at first glance may appear his opposite, in both age and background.

The biography of Domenico Savio as well the image of the young saint on its cover are central in yet another play set in the present time, Il birichino della SAMI [SAMI's little rascal] (1954) by Salesian priest Rufillo Uguccioni. ${ }^{44}$ The SAMI of the title is a factory where several teenage boys carry out minor duties: one is in charge of the elevator, another shines the brass plaques on the office doors, a third delivers packages on his bike between the warehouse and the factory, one works the switchboard and yet another opens and closes the main gate. However, the most important of these teenagers seems to be the one nicknamed Fox who watches over the vehicles left in the parking garage and who during breaks reads Domenico Savio's biography to his friends. Fox's leadership of the little group consists not only in reading an inspirational book; he also acts as Domenico Savio did,

40 A further play on Domenico Savio, Traguardo a quindici anni [Hitting the target at 15] by A. Garnier (1955), published in Teatro dei giovani in 1955, goes beyond the scope of this article, being a translation from a French work. The episodes of his life chosen for this play are mostly those already present in the other plays, plus some more wondrous ones (such as when he receives a premonition of a dying person needing a priest, or when he has a vision about England). The interest in this play consists mainly in its metatheatrical style, but also the presence of the devil—called Retro-on stage.

41 Francesca Sangiorgio was the penname of Clotilde Masci (1918-1985), who would use her real name in later years for her award-winning plays. See Cavallaro (2017, p. 228) for a short biography of Masci in English.

42 As Umberto Eco (2014) has remarked, the image of Domenico Savio that appears in holy cards, books and more recently websites has changed drastically throughout the decades. In the early 1940s a new portrait of the young man was commissioned to the painter and Salesian alumnus Mario Caffaro-Rore. Both Sangiorgio's and Uguccioni's plays most probably refer to that image. See Piola (2020) for a discussion of the different portraits of Domenico Savio.

43 An image of Domenico Savio is visible also in the wallet of one of his employees.

44 Rufillo Uguccioni SDB (1891-1966) authored dozens of novels and plays for youth, as well as the script for a film on don Bosco. 
tearing up an inappropriate publication that was given to his friends, and convincing them to stop listening to the anticlerical comments of their supervisor.

The actual plot thickens in the second act, when the supervisor denounces Fox to the factory owner as a church-sent infiltrator, presenting Fox's copy of Domenico Savio's biography as proof, and asking for Fox's dismissal. The factory owner, however, is himself in trouble because of a very important invoice that has been lost. Fox makes a bet with him that "his little saint" will help. At the end of the play, as the invoice is found, the owner is so grateful that instead of firing Fox, he hires his unemployed father, so that Fox can return to his studies-and promises that he will never forget what the "saintly little rascal" Domenico Savio has done for him.

While Domenico Savio himself is not a character in this play, his biography-the actual book, with its distinctive cover bearing a portrait of the young saint-is significantly prominent in every scene. When Fox presents the biography on stage, he states that it is his favorite book; he has read it several times already. As the boys are introduced, they mention that Fox is reading to them passages from the life of Domenico Savio, "a boy like us" (Uguccioni 1954, p. 60). In fact, the first scene begins with Fox reading to his mates the episode in which Savio interrupts a fight between two boys. The book subsequently becomes an object of contention with the older worker and is later obtained by the supervisor. Trying to recover his book, Fox meets with the factory owner who has received it and keeps it on his desk. The image on the cover-a teenager with a halo around his head-prompts an explanation from Fox, who vouches for the many graces and prayers which the saint has answered and suggests that praying to the image of the saint will help recover the important document that has been misplaced. As there is no time to buy an image of the saint and pray to him, Fox tears the book cover off and hangs it on the wall, inside an existing photo frame-behind which the lost document is found. Thanks to this plot device, the image of Domenico Savio is prominently shown on stage to the characters - and to the audience-for most of the play. As the play ends, the factory owner promises to leave the image on his wall, to buy new copies of the book for each of the boys employed in his factory, and to keep Fox's copy for himself, as he wants to read it. Thus, like La colomba nel sole, this play shows that, through the influence of his biography, Domenico Savio is able to continue his work of saving souls-of both young and old.

Il birichino della SAMI has a light-hearted, cheerful tone, very different from that of hagiographical plays - and yet, it demonstrates that Domenico Savio's example can still be useful in situations that are specific to the 1950s. When an older factory worker gives the teenagers a magazine to leaf through, the boys are attracted by the comic story format, the colourful pages, and the photo of an American movie star portrayed in a bathing suit. While no name is mentioned, it is not hard to recognize a typical glossy magazine such as Grand Hotel or Bolero film, publications that started in the post-WWII years with enormous success, catering for readers-mainly, but not exclusively female, as Bonifazio explains (Bonifazio 2020, p. 4) of low income and education-and usually censored by the Catholic Church (Morris 2007, p. 112; Bonifazio 2020, p. 113).

The second case of Fox imitating Savio-and even quoting from his biography - is when the supervisor comes to help the boys who are fighting with the factory worker over his magazine and Fox's book. The supervisor initially seems a friendly and supportive person: "I'm here to defend the freedom of opinions, which has to be guaranteed to everyone, men and boys. Work is what matters" (Uguccioni 1954, p. 64), he states. However, then the conversation moves to the book the boys are reading, and further to the pope and heaven. At that point, his opinions no longer match those of the boys:

SUPERVISOR: To each his own ideas. In my opinion, the workers' heaven is here and not up in the clouds. A good job, a good salary, that's all we ask.

FOX: And when you die?

SUPERVISOR: Then heaven will be finished for us but will start for our children, if we are able to defend our rights against the lies of capitalism. 
FOX: Yes, but where will you go, after you die?

SUPERVISOR: What? You don't know where dead people go after a funeral? Under ground.

FOX: Yes, the body. But the soul goes to heaven or hell!

SUPERVISOR: That's what priests say. They want to keep us quiet-with the lies of capitalists. Women and children might still believe that but we ... we're not fools. We don't take that bait. (Uguccioni 1954, p. 65)

Fox ends this conversation by referring to a similar person mentioned in Savio's biography, "a minion of the devil" (Uguccioni 1954, p. 66) who would discredit the clergy and the sacred. In Uguccioni's play, set in the years of the cold war, when Italy saw a bipolar division between the Catholic Church and the left-wing parties (Pollard 2003), it is not surprising that such a dangerous person may be identified with a materialist God-less person, marking this play as yet another example of anticommunist propaganda in Catholic educational theatre. ${ }^{45}$

A later work portraying Domenico Savio within the context of Salesian education combines past and present, and even suggests the future, again referring to Don Bosco's seminal biography. . $4 \ldots 4 \ldots 4$ : pezzi di paradiso $[\ldots 4 \ldots 4 \ldots 4 \text { : bits of heaven }]^{46}$ (1965), by Salesian priests Michel Mouillard and Marco Bongioanni, ${ }^{47}$ is defined as a "scenic play in three nocturnes", as it was conceived to be staged in the open and in the evening. ${ }^{48}$ Some of the characters are listed only as "voices", and the stage directions advise that such characters "could be evoked by symbolic figures that 'mime' the recorded voices" (Mouillard and Bongioanni 1965, p. 15). This use of a corporeal theatricality, and light and voice effects indicate a change in style from the traditional acted plays that presented the lives of St Agnes and St Domenico Savio that I have discussed so far.

The first "nocturne" is about the Virgin Mary calling Don Bosco in 1824 to take care of the youth; the second, entitled "The saints answer the call", stages the first meeting between Domenico Savio and Don Bosco in 1854. The character playing Don Bosco asks for the book he wrote on Savio's life to be brought to him, as a reminder and proof that the dialogue that the spectators are going to hear was faithfully recorded at the time. However, another voice - the voice of Satan - intervenes to plant doubts: Yes, Domenico Savio was a model of charity, generosity, and purity - but what sort of youth would Don Bosco see in the Salesian oratories and schools in 1965? The answer comes in nocturne three, "The echo in the world", which is set in the present time. This last nocturne refers to the day of Savio's canonization, and to the positive influence that the young saint would have on youth for decades to come: "Domenico was given to them as friend", Don Bosco explains, so that they might be able to navigate modern life, with all its neon lights and electronics, its automation and Cinerama (Mouillard and Bongioanni 1965, p. 25). ${ }^{49}$ Savio himself confirms that he has not forgotten today's youth and hopes to lead them to become faithful friends of Christ. The play's finale, with light effects, mimed actions, and final fireworks, proclaims: "From all five continents young people will rise, and among them there will be saints; [ ... ] Domenico always, Domenico everywhere" (Mouillard and Bongioanni 1965, p. 26).

45 See Cavallaro (2017, pp. 78-85) for other examples of anticommunism in educational plays. It seems also quite likely that those "enemies who would like to separate us from Christ" (Duranti 1963, p. 79) and the corrupting speeches mentioned in Il processo di santa Agnese refer to the Communist threat against young Christian souls.

46 The title refers to a well-known saying by Don Bosco, "Un pezzo di paradiso aggiusta tutto" [A bit of heaven will put everything right] (Le Massime di Don Bosco 1999, p. 95).

47 Marco Bongioanni SDB (1920-1990) authored a great number of plays and books on the use of theatre and cinema within Salesian education. Beginning in 1951 he also edited of both Teatro dei giovani and Teatro delle giovani.

48 The play premiered on the evening of 13 April 1965 in the square of the Basilica of Our Lady Helper of Christians in Turin. The actors were students of Salesian schools from Algeria, Belgium, France, and Switzerland (Mouillard and Bongioanni 1965, p. 15).

49 In .. . . . . 4: pezzi di paradiso, the threats to young people's souls are not so much inappropriate readings, as in earlier plays, but rather the risks of the automatization of modern life. At the very end, in line with the times and the fear of wars, a pacifist message is also included. The young voices proclaim that the world will not make of them "robots" or "cannon fodder" (Mouillard and Bongioanni 1965, p. 26). 
Together with its quick temporal changes-so quick that even a stage technician calls out to complain that the audience should be informed that the action now takes place in the present (Mouillard and Bongioanni 1965, p. 23) ${ }^{50}$ —and self-referential lines, this play was probably meant to appeal more to the spectators' sense of wonder than to their intellectual understanding of the episodes of Savio's life. Compared to other worldly and wildly imaginative moments (such as Satan's phone call to Don Bosco), the snippets taken from the biography written by Don Bosco would probably have been forgotten. Lastly, the play also included elements of a traditional celebration for a feast-day of a saint-choirs of voices proclaiming the sanctity of Domenico Savio, and the fireworks finale. However, even considering this modernized style of theatrical presentation, two fundamental elements present in the earlier Domenico Savio plays remain the same: the dialogues exchanged by Don Bosco and his pupil Domenico Savio begin by using Don Bosco's biography as the source; and the message of the play confirms the positive effect that the young saint will have long after his death.

\section{Conclusions: The Voice of the Saints in Salesian Theatre}

A famous story about the life of Don Bosco reports that in 1880 the future saint was about to attend a theatrical performance in his honour when he was informed that the young protagonist, a 12-year-old boy, had lost his voice. Don Bosco told the boy that he would lend him his own voice, so that the boy could perform properly. The boy recovered his voice, while Don Bosco remained aphonic for the duration of the successfully staged show. Marco Bongioanni, who in 1965 recounted this episode, concluded: "Theatre has the voice of the saints. Let us allow the theatre to speak" (Bongioanni 1965, p. 6).

Bongioanni, of course, used this anecdote to underline Don Bosco's interest in and attachment to the theatrical medium as a way to educate youth, as well as to trace the tradition which connected the educational system envisioned by the saint with the continuing theatrical practice and publications of the Salesians even in the mid-1960s. And in fact, my analysis of the plays devoted to St Agnes and St Domenico Savio published in Salesian theatre magazines have shown how the saints' voices continued to resonate on the stage several decades after that perhaps apocryphal episode of 1880-indeed, in the two decades following the end of World War II.

The main purpose of the plays, of course, was to offer a role model for the young actors and their audiences-an "example in their way of life", to use the already cited words of Lumen gentium. The Salesians thought that theatre, more than any other medium, could inspire especially those who performed in it. In a 1958 talk, author Caterina Pesci highlighted the powerful effect of playing the role of a saint or a heroine for a young actress, who would thus strive to become a character "greater than herself", concluding with the hope that "the transitory heroism acted on the stage" may also in some cases become "a perennial life privilege" (Pesci 1958, pp. 8-9). Members of the audience would also be positively affected by a message of faith performed on stage: "when girls and young women appear on stage transformed into saints or queens, parents will believe they are witnessing almost a miracle, and accept the great words of Christian truth and morality because they come from a dear voice", Pesci wrote in another occasion (Mariangel 1957, p. 2). ${ }^{51}$ Reports of stagings of the play Un angelo in portineria on Domenico Savio state that the audience left with "teary eyes", as the life of the young saint "appeared on stage as a live vision", passing on its message of goodness and generosity ("Applausi e commenti" 1955a, p. 75). The same play staged in a Salesian community in Nagatsu Kyushu (Japan) "raised admiration among Christians, pagans and catechumens. After the play many were the boys who stated that they wanted to become as good as St Domenico, and they said it with such sincerity and conviction to cause tear" ("Applausi e commenti" 1955b, p. 91).

\footnotetext{
50 Members of the audience familiar with Italian theatre would recognize similarities between the character of the stage technician and that of the Director in Luigi Pirandello's Six characters in search of an author (1921).

51 Mariangel was a penname which Pesci frequently used (Ossi 1990, vol. 1, p. 233).
} 
"People today do not go to church to be catechized", concluded Pesci, "but they do accept catechism in the theatre" (Pesci 1958, pp. 8-9).

Both St Agnes and St Domenico Savio were teenagers who died young, striving to maintain a life without sin. And purity of life was certainly a message that the Salesians wanted to transmit to their young students and oratorians. However, I would argue that the Italian plays on St Agnes and Domenico Savio published in Teatro dei giovani and Teatro delle giovani in the 1950s and 1960s, while stressing the fact that the two saintly teenagers tried to avoid all sins, mostly focused on their apostolate, on their actions that would convert others from a life of sin. ${ }^{52}$ The plays on St Agnes' life show how her example converted many - her friends, her slaves, the enemies of Christianity, even those who denounced her-to Christianity. The plays set in modern times suggest that her lasting example and a continued relationship with her will strengthen the resolve of young women amid the many temptations offered by cinema, books, magazines, and friends.

Domenico Savio, as portrayed in the educational plays of the 1950s and '60s, followed Don Bosco's recommendation that the best path toward sanctity is to save other people's souls. Thus, he worked to make sure that other young people like himself would not sin. As the plays were all based on Don Bosco's biography of Domenico Savio, to the point of even bringing the actual book on stage, just like the biography they characterised Savio's life example as not "simply one of personal holiness (devotion, prayer, duty, obedience, purity, penance, etc.)", but also of "holiness through the apostolate, the practical exercise of charity" (Lenti 2001, p. 49). ${ }^{53}$ From Domenico Savio—dai campi alle stelle of 1950 to . . 4 . . 4 ... 4: pezzi di paradiso of 1965, Domenico Savio is extolled for both his own life choices and his work-during his life and beyond-for the salvation of young people who from all continents try to follow in his footsteps.

However, these plays also showed how Savio's example during his life and after his death contributed to lead adults to repent and move toward a life of faith and prayer. At the end of Un angelo in portineria, arrogant Mr Prati understands that Savio has profoundly changed the life of his son-and also realizes that there may still be time to save his own. At the end of act 1 of La colomba nel sole, Mr Aloisi addresses the young saint "with the desperation of one who is drowning": "Help me, little saint [ ... ] have mercy of me" (Sangiorgio 1950, p. 13). By the end of act 2, he will fall to his knees and ask the little saint to teach him to pray. The final words of Il birichino della SAMI are also addressed directly to the young saint, whose image has now taken a permanent place in the office of the factory owner: "And now to us, little rascal! I should probably kneel before a saint but let's consider you just as you are: a nice young man. And let me just tell you: you have done me such a great service. I'll never forget that (Uguccioni 1954, p. 74).

Furthermore, especially in the hagiographic plays that were set in more contemporary times, the authors managed to convey not only the spiritual message that referred to the life of the protagonist, but also a reference to the specific social conditions of the time when they were created and performed. Thus, a new Agnes may decide to devote her life to Christ by working in a hospital; a new Domenico Savio may have to defend the clergy against abuse from the communists.

In sum, the saint plays published in Teatro dei giovani and Teatro delle giovani and performed in the 1950s and early 1960s in Italian schools, oratories and on local stages seem to have been an essential and effective part of the Salesian educational commitment

52 For example, one famous episode in the biography of Domenico Savio was his refusal to swim with his mates. The episode is introduced by the narrating voice (Don Bosco's) who explains that the gathering of many - unclothed - youth in rivers, brooks or lakes is dangerous for their bodies but even more so for their souls: "How many boys bemoan the loss of their innocence identifying the origin in going swimming with their mates in those wretched places!". Savio, in fact, refused the invitation saying that by swimming "there is risk of drowning or offending the Lord". Don Bosco concludes that by not going swimming, Savio "avoided a great danger, in which [ ... ] he would possibly have lost the invaluable treasure of his innocence" (Bosco 1878, chapter IV). None of the plays on Savio I have discussed stage that episode, which would have been a symbol of his desire to remain pure, without being exposed to the naked bodies of his mates or showing his own. It is possible that the plays avoided the episode in order to not even suggest the possibility of impure thoughts. In any case, as a result they concentrate on Savio's mission to help others rather than on his own wish for "death, but not sin" (Bosco 1878, chapter III).

53 Lenti's words here refer to the biography, not the plays. 
to youth. Such plays allowed performers and audiences to learn Catholic values and faith in a way that was immediate, moving, and effective in terms of catechesis. Young actors would make the voices of the saints their own, transmitting their faith, fears, and spiritual struggles. Families and friends would listen to a message of faith and apostolate that came not from the pulpit, but from the voice of their beloved children. Salesian theatre, in sum, was working toward that "cultural and moral betterment of audiences" that the decree Inter mirifica expected from drama (Inter mirifica 1963, chapter II, 14).

In the mid-1960s, Salesian theatre took a different direction in terms of both form and content. As already surmised from the style of .. 4. .4 . 4: pezzi di paradiso, improvisation, gesturality and creativity became far more predominant than the staging of written plays. The so-called teatro d'espressione [theatre of creative expression] required a minimal script, as the participants themselves were expected to create every aspect of the performance, from plot and gestures to lights and costumes. It might consist of mime, singing, diction, dancing or even paraliturgies. Furthermore, a wider acceptance of mixed groups of boys and girls (as also promoted by the new school legislation of 31 December 1962) led educational theatre authors to create less gender-specific plots. Again, .. . 4 .. 4 . . 4: pezzi di paradiso, with its mixture of male and female voices, and the use of gender-neutral "symbolic figures" (Mouillard and Bongioanni 1965, p. 15) may give an idea of the changes that were beginning to take place in both Italian society and Salesian theatre.

At the same time, moreover, the editor and the authors of Salesian theatre publications were worried about a crisis of Catholic theatre, due to competition with other pastimes such as soccer tournaments, jukeboxes, television, and especially cinema. Due to the popular request to have movie screens available in parishes, and because it was far easier to show a film than to rehearse and perform a play, many local stages were dismantled, and many theatre publications ceased to exist. In 1966 Teatro dei giovani and Teatro delle giovani merged, with the content aimed more specifically to young men in even months and young women in odd months (Cavallaro 2017, pp. 55-58).

The last issue of Teatro delle giovani which announced the upcoming merging, also reported pope Paul VI's address to artists, given in St Peter's Square on 8 December 1965, at the end of the Second Vatican Council ("Il Concilio" 1965). In that speech, the pope called upon artists to continue to work to transmit beauty and truth to the world, disregarding those "tastes which are passing and have no genuine value": "Today, as yesterday, the Church needs you and turns to you. She tells you through our voice: Do not allow an alliance as fruitful as this to be broken. Do not refuse to put your talents at the service of divine truth. Do not close your mind to the breath of the Holy Spirit" ("Address of Pope Paul VI to Artists" 1965). Another speech also quoted in the same article of Teatro delle giovani, given by the pope just a week later, on 15 December 1965, to representatives of Italian artists of theatre and cinema, was even more specific in attributing great responsibility to those who work in the performing arts: "You are the most powerful vehicle of suggestion on people, on your spectators; you are an enchanting channel of feelings, passions, experiences, dreams and ideas, that you transmit to those who watch you". Thus, the pope concluded, it is essential that the arts offer "not poison, but balm; not vertigo, but vision" ("Il Concilio" 1965, pp. 8, 55). ${ }^{54}$ By quoting the pope's words regarding the power of the arts and the responsibility of the artists, the Salesians reaffirmed their commitment to the Christianising mission of their theatre-in any style or expression.

And, in fact, that reaffirmation has borne fruit. Theatrical tradition in Salesian schools continues still today, and the lives of the saints are still considered appropriate material for new theatrical pieces, even though in different format. While St Agnes may have lost some of her appeal, the characters of Don Bosco, ${ }^{55}$ his successor Fr Rua, ${ }^{56}$ Maria Mazzarello, ${ }^{57}$

54 For the entire address in Italian, see Paolo VI (1965).

55 Italian musicals on Don Bosco include Andiamo ragazzi! by Paola Pignatelli and Raffaele Lo Buono (2008); C'è da non crederci by Ivo Valoppi (2012); Fino all' ultimo mio respiro by Alessio Allegretti (2013); and Don Bosco: il musical by Piero Castellacci with Renato Biagioli (2016).

56 Io ci sto! by Giuseppe Lapergola and Simone Calvano (2011).

57 Sei con noi by Matteo Pantani (2014). 
Salesian-educated blessed Ceferino Namuncurá, ${ }^{58}$ and of course Domenico Savio himself, ${ }^{59}$ continue to be the protagonists of many Italian musicals created for local communities of Salesian students, alumni and families, wherein the voices of the saints still resonate on stage to offer life example, fellowship and intercession for all.

Funding: This research received no external funding.

Acknowledgments: The author would like to acknowledge the members of the Salesian orders who have given her access to the primary texts discussed in this article: Tadeusz Lewicki SDB, Michele Novelli SDB, Renata Piovesan FMA. Many thanks also to Barbara Martelli for her research assistance.

Conflicts of Interest: The author declares no conflict of interest.

\section{References}

“Address of Pope Paul VI to Artists". 1965. December 8. Available online: http://www.vatican.va/content/paul-vi/en/speeches/19 65/documents/hf_p-vi_spe_19651208_epilogo-concilio-artisti.html (accessed on 4 March 2020).

“Applausi e commenti". 1955a. Teatro dei giovani 1: 73-79.

"Applausi e commenti". 1955b. Teatro dei giovani 10: 74-91.

"Ẽ Padre Pio il santo più famoso d'Italia. I meno invocati sono Gesù e la Madonna". 2006. La Repubblica. October 31. Available online: https: / / www.repubblica.it/2006/10/sezioni/cronaca/padre-pio/padre-pio/padre-pio.html (accessed on 21 July 2020 ).

“Il Concilio Vaticano II e Paolo VI confermano una lunga amicizia con l'arte". 1965. Teatro delle giovani 11-12: 6-8, 55.

"Saint Agnes". n.d.a Encyclopedia Britannica. Available online: https:/ /www.britannica.com/biography/Saint-Agnes (accessed on 15 September 2020).

"Saint Agnes". n.d.b Catholic Online. Available online: https://www.catholic.org/saints/saint.php?saint_id=106 (accessed on 15 September 2020).

"Siamo Figlie di Maria Ausiliatrice". 2019. Available online: https:/ / www.fmairo.net/chi-siamo/ (accessed on 15 September 2020).

"These vesting prayers before Mass remind priests of their unique vocation". 2018. aleteia.org. Available online: https://aleteia.org/ 2018/09/26/these-vesting-prayers-before-mass-remind-priests-of-their-unique-vocation/ (accessed on 15 September 2020).

Acchiappati, Maria Emma. 1939. Fiori di martiri, ossia fede intrepida. Torino: Istituto Figlie Maria Ausiliatrice.

Anania, Francesca. 2008. I nuovi impresari del culto dei santi: Radio e televisione. Sanctorum 5: 115-30.

Baaden, James. 2014. Post-War Saints: 1945-60. History of European Ideas 40: 873-92. [CrossRef]

Bandurski, Carolina. 2009. The Rappresentazione di Santa Cecilia Vergine e Martire Written by Suor Cherubina Venturelli. In Scenes from Italian Convent Life: An Anthology of Convent Theatrical Texts and Contexts. Edited by Elissa B. Weaver. Ravenna: Longo, pp. 37-51.

Bennett, Oliver. 2011. Strategic canonisation: Sanctity, popular culture and the Catholic Church. International Journal of Cultural Policy 17: 438-55. [CrossRef]

Biesmans, Rik. 1999. Aesthetics in Don Bosco's Educational System (1876-1884). Journal of Salesian Studies 10: 145-68.

Bini, Luigi. 1958. Piccolo sognatore (Giovannino Bosco). Teatro dei giovani 6-8: 51-66.

Boisvert, Donald L. 2015. The Construction of a Sexual Pedagogy. Childhood and Saints in Roman Catholic Discourse. In Religion and Sexuality: Diversity and the Limits of Tolerance. Edited by Pamela Dickey Young, Heather Shipley and Tracy J. Trothen. Vancouver: UBC Press, pp. 169-89.

Boisvert, Donald L. 2018. The Queerness of Saints: Inflecting Devotion and Same-Sex Desire. In New Approaches in History and Theology to Same-Sex Love and Desire. Edited by Mark D. Chapman and Dominic Janes. New York: Palgrave Macmillan, pp. $249-64$.

Bongioanni, Marco. 1965. Ottantesimo anno. Teatro delle giovani 1-2: 6.

Bonifazio, Paola. 2020. The Photoromance: A Feminist Reading of Popular Culture. Cambridge: The MIT Press.

Bosco, Giovanni. 1878. Vita del giovanetto Savio Domenico allievo dell'Oratorio di S. Francesco di Sales con appendice sulle grazie ottenute per sua intercessione, 5th ed. Torino: Tipografia e Libreria Salesiana.

Bosco, Giovanni. 1914. The Life of Dominic Savio. London: Salesian Press, Available online: http://www.traditionalcatholic.net/ Tradition/Information/Saint/John_Bosco/The_Life_of_Dominic_Savio/index.html (accessed on 6 June 2020).

Braido, Pietro. 1999. Prevention, not Repression: Don Bosco's Educational System. Rome: Istituto Storico Salesiano.

Caimi, Luciano. 1988. Popolo e educazione cristiana: Gli oratori. In Chiesa e progetto educativo nell'Italia del secondo dopoguerra. $1945-1958$. Brescia: La Scuola, pp. 210-38.

Caliò, Tommaso. 2008. 'Il miracolo in rotocalco'. Il sensazionalismo agiografico nei settimanali illustrati del secondo dopoguerra. Sanctorum 5: 23-50.

Caliò, Tommaso, and Roberto Rusconi. 2008. Le devozioni nella società di massa. Sanctorum 5: 5-8.

58 Il principe della Patagonia by Tommaso Sbardella (2020).

59 Italian musicals on Domenico Savio include Storie per vivere (on Savio, Michele Magone and Laura Vicuña) by Giuseppina Costa, Armando Bellocchi and Giuseppina Bellocchi (1999); A.A.A. Buona Stoffa Cercasi by Matteo Milanese and Cristian Siso (2000); Minot davvero speciale (2001) by Cesare Orfini, Alberto Piastrellini, Claudia Morichetti; and Accadde per strada by Silvana Papandrea (2015). 
Castellino, Onorato. 1920. Domenico Savio. Scene biografiche in tre atti. Torino: Sei.

Cavallaro, Daniela. 2011. Salesian Theatre for Young Women in post-World War II Italy. Ecumenica 4: 25-50.

Cavallaro, Daniela. 2013. Demons and Angels: Morality Plays in the Context of Salesian Educational Theatre for Young Women. The International Journal of Religion and Spirituality in Society 2: 43-52. [CrossRef]

Cavallaro, Daniela. 2017. Educational Theatre for Women in Post-World War II Italy. A Stage of Their Own. London: Palgrave Macmillan.

Cervera, Juan. 1976. Historia crítica del teatro infantil español. Universidad de Valencia. Available online: http:/ / www.cervantesvirtual. com/servlet/SirveObras/01472842099104951054480/index.htm (accessed on 4 March 2020).

Civitelli, Alessia. 2007. L'oratorio delle Figlie di Maria Ausiliatrice a Torino Valdocco all'inizio del '900. In L'educazione salesiana dal 1880 al 1922. Istanze ed attuazioni nei diversi contesti. Edited by J. Gonzalez, G. Loparco, F. Motto and S. Zimniak. Roma: LAS, vol. I, pp. 345-75.

da Sanfelice, Ivo. 1950. Domenico Savio—dai campi alle stelle. Teatro dei giovani 3: 25-43.

Duranti, Elisa. 1953. Agnese. Teatro delle giovani 5: 61-64.

Duranti, Elisa. 1963. Il processo di Sant'Agnese. Teatro delle giovani 3-4: 77-80.

Ebert, Roger. 2010. Mary We Crown Thee with Blossoms Today! rogerebert.com. Available online: https://www.rogerebert.com/ roger-ebert/mary-we-crown-thee-with-blossoms-today (accessed on 10 September 2020).

Eco, Umberto. 2014. Rappresentazioni del sacro. California Italian Studies 5: 1. Available online: https://escholarship.org/uc/item/ 7wc05003 (accessed on 10 September 2020).

F. M. A. 1956. Il fiore e la croce. Teatro delle giovani 9-10: 41-52.

Fornara, Flora. 1965. Gran festa in paradiso. In Carosello festivo. Roma: LES, pp. 108-13.

Frazier, Alison Knowles. 2005. Possible Lives. Authors and Saints in Renaissance Italy. New York: Columbia University Press.

Gallo, Anne-Sophie. 2018. Jesuit Theater. In The Oxford Handbook of Jesuits. Edited by Ines G. Županov. Oxford: Oxford University Press.

Garnier, A. 1955. Traguardo a quindici anni. Teatro dei giovani 6: 65-107.

Garro, Emilio. 1949. San Tarcisio. Teatro dei giovani 12: 3-43.

Goretti, Leo. 2012. Irma Bandiera and Maria Goretti: Gender role models for communist girls in Italy (1945-56). Twentieth Century Communism 4: 14-37. [CrossRef]

Gorla, Stefano. 2008. Tra nuvole e aureole: Il fumetto agiografico. Sanctorum 5: 89-113.

Grignaffini, Giovanna. 1994. Sante e suore sullo schermo. In Donne e fede: Santità e vita religiosa in Italia. Edited by Giulia Barone, Lucetta Scaraffia and Gabriella Zarri. Roma: Laterza, pp. 517-30.

Inter mirifica. 1963. Decree on the Media of Social Communications Solemnly Promulgated by His Holiness Pope Paul VI on December 4. Available online: http://www.vatican.va/archive/hist_councils/ii_vatican_council/documents/vat-ii_decree_19631204 _inter-mirifica_en.html (accessed on 5 December 2020).

L'educazione del sentimento attraverso il teatro. 1950. Teatro delle giovani 3: 1-2.

Le Massime di Don Bosco. 1999. Available online: https:/ /www.donboscoland.it/uploads/dedd421ed86458d735ae7c926402a7c8.pdf (accessed on 15 December 2020).

Lenti, Arthur J. 2001. Don Bosco’s Second Great Hagiographical Essay ‘The Life of Young Dominic Savio’. Journal of Salesian Studies 12: $1-52$.

Lewicki, Tadeusz. 2012. The Historical Origins of Salesian Theatre. Divyadaan: Journal of Philosophy and Education 23: 199-210.

Lumen gentium. 1964. Dogmatic Constitution on the Church Solemnly Promulgated by His Holiness Pope Paul VI on November 21, 1964. Available online: http://www.vatican.va/archive/hist_councils/ii_vatican_council/documents/vat-ii_const_19641121 _lumen-gentium_en.html (accessed on 10 September 2020).

Maccono, Ferdinando. 1910. Piccolo manuale dell'Associazione di Maria Ausiliatrice per le giovinette. Torino: Libreria Editrice Società Buona Stampa.

Marescalchi, Amilcare. 1921. Domenico Savio: Scene episodiche in tre atti. Vicenza: G. Galla.

Mariangel. 1957. Una constatazione e un elogio. Teatro delle giovani 3-4: 1-3.

Morris, Penelope. 2007. The Harem Exposed: Gabriella Parca's Le italiane si confessano. In Women in Italy, 1945-1960: An Interdisciplinary Study. Edited by Penelope Morris. New York: Palgrave Macmillan US, pp. 109-30.

Mouillard, Michel, and Marco Bongioanni. 1965. . . 4 . . 4 . 4: Pezzi di paradiso. Teatro delle giovani 3-5: 15-26.

Muneroni, Stefano. 2017. Hermenegildo and the Jesuits. Staging Sainthood in the Early Modern Period. Cham: Palgrave Macmillan.

Muneroni, Stefano. 2019. Sforza Pallavicino-Martyr Hermenegild. Toronto: Centre for Reformation and Renaissance Studies Press.

Ossi, Maria. 1990. Una donna di futuro. Caterina Pesci. Roma: Istituto Figlie di Maria Ausiliatrice.

Paolo VI. 1965. Udienza generale. Mercoledì 15 dicembre. Available online: http://www.vatican.va/content/paul-vi/it/audiences/19 65/documents/hf_p-vi_aud_19651215.html (accessed on 20 September 2020).

Perugini, Sergio. 2011. La fiction religiosa italiana anni Novanta e Duemila: Storie di santi, papi e preti esemplari. Cantalupoa: Effatà.

Pesci, Caterina. 1950. Fiori nel turbine. Teatro delle giovani 5: 3-52.

Pesci, Caterina. 1951. Lei, la prima. Teatro delle giovani 6: 19-53.

Pesci, Caterina. 1954a. Il velo insanguinato. Teatro delle giovani 6: 13-38.

Pesci, Caterina. 1954b. Per la festa di S. Agnese. Teatro delle giovani 6: 39-42.

Pesci, Caterina. 1956. Sulle sue tracce. Teatro delle giovani 11-12: 11-23. 
Pesci, Caterina. 1958. Salviamo il nostro teatro. Teatro delle giovani 5-6: 7-9.

Pesci, Caterina. 1961. Per te, mamma! Teatro delle giovani 8-10: 37-62.

Piola, Lorenzo. 2020. Il vero volto di Domenico Savio. Available online: http:/ / www.inoratorio.it/il-vero-volto-di-san-domenico-savio (accessed on 20 December 2020).

Pollard, John. 2003. The Vatican, Italy and the Cold War. In Religion and the Cold War. Edited by Dianne Kirby. Houndmills, Basingstoke, Hampshire. New York: Palgrave, pp. 103-17.

Pulci, Antonia. 1996. Florentine Drama for Convent and Festival: Seven Sacred Plays. Chicago: University of Chicago Press.

Pulci, Antonia. 2010. Saints' lives and Bible stories for the stage. Toronto: Centre for Reformation and Renaissance Studies.

Renoglio, Ersilio. 1957. Ragazzo santo. Teatro dei giovani 1: 58-61.

Salvestrini, F. 1949. Nella luce di un centenario. Teatro dei giovani 1: 62-64.

Sangiorgio, Francesca. 1950. La colomba nel sole. Teatro dei giovani 3: 3-24.

Sani, Roberto. 2009. "Ad Maiorem Dei Gloriam". Istituti religiosi, educazione e scuola nell'Italia moderna e contemporanea. Macerata: EUM-Edizioni Università di Macerata.

Stagnoli, Saverio. 1967-1968. Don Bosco e il teatro educativo salesiano. Estratto da Eco degli Oratori. Available online: http:/ /www. salesian.online/wp-content/uploads/2021/03/TEATRO-EDUCATIVO-SALESIANO.pdf (accessed on 4 December 2020).

Stella, Pietro. 2005. Il modo di lavorare di Don Bosco. In Domenico Savio raccontato da Don Bosco. Riflessioni sulla Vita. Edited by A. Giraudo. Roma: LAS, pp. 11-30.

Stella, Pietro. 2009. Per una storia dell'agiografia in età contemporanea. Il "giovanetto Savio Domenico" (1859) di san Giovanni Bosco. In Vita religiosa, problemi sociali e impegno civile dei cattolici. Studi storici in onore di Alberto Monticone. Edited by A. Sindoni and M. Tosti. Roma: Editrice Studium, pp. 143-67.

Tettamanzi, Dionigi. 2004. Anche voi come Domenico Savio testimoni gioiosi di santità. March $9 . \quad$ Available online: https:/ / www.chiesadimilano.it/cms/documenti-del-vescovo/tettamanzi/dt-omelie/anche-voi-come-domenico-saviotestimoni-gioiosi-di-santita-14523.html (accessed on 20 December 2020).

Tondo, Lorenzo. 2020. Palermo pins hopes on patron saint to rid Italy of coronavirus. The Guardian. March 13. Available online: https:/ / www.theguardian.com/world/2020/mar/13/palermo-pins-hopes-patron-saint-rosalia-rid-italy-coronavirus (accessed on 20 December 2020).

Toselli, Laura. 1959. La cintura di Agnese. Teatro delle giovani 11-12: 40-49.

Uguccioni, Rufillo. 1954. Il birichino della SAMI. Teatro dei giovani 8: 57-74.

Vettori, T. M. 1952. L'angelo in portineria. Teatro dei giovani 6: 19-75.

Weaver, Elissa B. 2002. Convent Theatre in Early Modern Italy: Spiritual Fun and Leaning for Women. Cambridge: Cambridge University Press.

Wetzel, Donald. 2014. Is it Possible to Be Queer and Catholic? Overcoming the 'Silence of Sodom'. In Queering Religion, Religious Queers. Edited by Yvette Taylor and Ria Snowdon. New York: Routledge, pp. 61-81.

Wiseman, Nicholas. 1885. Fabiola. The Church of the Catacombs. Available online: https://www.gutenberg.org/files/62254/62254-h/ 62254-h.htm (accessed on 20 December 2020). 